\title{
SOUTH AFRICA AND THE AFRICAN UNION'S PEACE AND SECURITY ARCHITECTURE: OLD RESPONSIBILITIES AND NEW CHALLENGES
}

John Akokpari ${ }^{1}$

\section{Introduction}

The Organisation of African Unity (OAU) was officially replaced by the African Union (AU) in July 2002. As the largest regional body, the AU was tasked with uniting the continent and promoting Africa's development. One of the reasons for the demise of the OAU was its demonstrated inability to adapt to the global changes taking place after the Cold war and in particular to respond to the new set of challenges and opportunities facing the continent. These challenges include Africa's marginalisation in the global economy, its growing international indebtedness, as well as domestic constraints such as HIV/AIDS, governance and, more crucially, internal conflicts. The OAU remained largely invisible on these issues, and as Packer and Rukare noted, the organisation was only "discussed for many years within and outside its headquarters in Addis Ababa" (Packer and Rukare $2002,365)$. The failures of the OAU in a new global context rendered it obsolete. There was thus popular expectation within the continent for the AU to become more assertive and to succeed where the OAU failed. To distinguish itself from the failings of its predecessor, the AU put a peace and security architecture (PSA) in place aimed at preventing, but also managing conflicts, which became a defining feature of Africa's political economy. While the AU's PSA has been hailed for providing a new approach to peace, security and governance, it was criticised for its incapacity to surmount the many challenges facing it, including the failure of some member states to fully support AU resolutions. In some instances, some countries openly

I Department of Political Studies, University of Cape Town, Cape Town, South Africa. Email: john.akokpari@uct.ac.za 
contradicted the stance of the AU.

This paper highlights the challenges facing the AU's PSA. It notes that one of these challenges is the contradictory position of South Africa on some of the peace and security decisions of the AU, including the disputed election results of the Ivory Coast presidential election of November 20I0, and the Libyan crisis in March 20II. The paper argues that the AU also faces challenges relating to inadequate funds and the reluctance of member states to readily contribute troops for peacekeeping operations (PKOs). Together, these challenges vitiated the efforts of the AU to speedily resolve conflicts and other threats to regional peace and security. In addressing this and related issues, the paper underscores Africa as a theatre of conflicts. Next, it outlines the key features of the AU's peace and security architecture, and then highlights the challenges facing the peace and security project. The conclusion summarises the main points in the paper.

\section{Africa: the continent of conflicts}

The scale and frequency of Africa's conflicts are too familiar to be recounted. However, suffice it to say that no fewer than 80 conflicts were recorded in Africa between I960 and the early I990s (Adedeji I999, 3), many of which occurred in the aftermath of the Cold War. Moreover, a majority of the conflicts were intra-state. In spite of the global decrease in the number of inter-state wars after the Cold War, Africa has seen an increase in the number of intra-state conflicts (Goodhand 2006, 79). For example, Laremont observed that only two - the Chad/Libya and the Rwanda/ Uganda - wars were interstate among the total of 16 wars that occurred on the continent between I990 and 1997 (Laremont 2002, 3). While intrastate conflicts continue to proliferate, the only full-scale inter-state conflicts since the dawn of the new millennium were the Ethiopian-Eritrean border war, which continues to re-erupt intermittently and, until 20II, the North and South Sudan conflict. The ubiquity of conflicts in Africa was further revealed in the fact that while i3 percent of the world's conflicts were fought in Africa in the I960s, this figure escalated to 35 percent by the beginning of the $2 \mathrm{I}^{\text {st }}$ century.

Africa's notoriety as a leading theatre of conflicts is revealed, moreover, in the fact that it currently hosts the largest UN peacekeeping contingent of about 22,492 (made up of troops, police, military observers and UN volunteers) in the UN Stabilisation Mission in the DRC MONUSCO (United Nations 20I6). The mutiny of soldiers loyal to Bosco Ntaganda, a former general of the Congolese military in April 2012, and 
the continuing instability in Eastern DRC where rebel Ntaganda is based, does not suggest the withdrawal of MONUSCO anytime soon. The UN also maintains a hybrid AU-UN force (UNAMID) in Darfur, Sudan, which by January 2016 numbered 2I,022 (ibid); and a stabilisation force of 7,I20 in the UN Operation in Cote d'Ivoire - UNOCI (ibid). As well, the AU Mission in Somalia (AMISOM) had a paltry force of 5,000 by August 20II, before the figure was augmented by Kenyan troops, who entered Somalia in September 2OII in pursuit of Al-Shaabab militants suspected of being behind the spate of kidnappings and bombings in Kenya and parts of East Africa.

Equally remarkable, about Africa's intra-state conflicts, is the upsurge in the use of child soldiers on battle fronts. The conflicts in Liberia, Sierra Leone, the DRC and the rebel war in northern Uganda involving the Joseph Kony-led Lord Resistance Army (LRA) and the Ugandan national army, have all involved the use of child soldiers. At the height of the Sierra Leonean conflict between 1992 and 1996 , for example, an estimated 4,500 children, many of whom were I4 years or younger, were forcefully recruited by the Revolutionary United Front - RUF (Skinner I999, I0). Similarly, in Northern Uganda children between the ages of Io and I8 were routinely abducted by the LRA and used as soldiers, while girls were used as "comfort women" (MacMullin and Loughry 2004). Other features of Africa's conflicts have been the systematic rape, which rebels often visit on women; the inhumane maiming and amputation of civilian limbs (Laremont 2002, I4) as well as the growing incidences of HIV/AIDS infections among soldiers and rebels (Ndinga-Muvumba 2008). The increasing use of terrorist tactics, such as scotched earth methods, the use of explosives against soft targets especially civilians, has become new defining features of conflicts in Africa. Militant fundamentalist groups, including Al Shaabab in Somalia and Boko Haram in Nigeria have in the last few years resorted to the systematic use of terror against the AU Mission in Somalia (AMISOM) and the Nigerian population respectively. These conflicts have led to deaths, destruction of property, the weakening of the already fragile institutions of governance, and a massive threat to peace and security.

While the reality and wider implications of conflicts for Africa's peace and security are beyond dispute, the causes have elicited a wide range of explanations. A popular explanation of Africa's conflicts has been linked to the struggle over the state and resources. Goran Hyden notes that, Africa's conflicts are increasingly over natural resources (Hyden I992, 2). Accordingly, Africa's conflicts are now increasingly referred to as "resource conflicts." Other observers attribute the causes to political and governancerelated factors such as neopatrimonialism, corruption, poor leadership, disrespect for human rights and democracy (Guest 2004), while others 
trace the causes to economic adversities and poverty (Adekanye I995; Brown I995). Other analysts, too, link it to the partisan posture of the state and its tendency to marginalise certain communities, which leads to irredentism and secessionist sentiments (Adam I995; Adejumobi 200I; Akokpari 2008) while yet others view African conflicts as reflecting contestation over farming and grazing lands and other diminishing environmental resources. These analysts refer to Africa's conflicts as essentially "eco-wars" (Suliman and Omer I994). Further, others see conflicts as a reflection of the fragility of the African state and the pervasiveness of ethnic politics (Copson I994). The rise of religious fundamentalism has also become a new cause of conflicts in Africa. These various perspectives underscore the complexity of the causes of Africa's conflicts and the illusiveness of a single causal explanation.

A visible failing of the OAU has been its inability to address issues around governance whose effects often resulted in conflicts. Poor governance was reflected in the emergence of authoritarian and largely unaccountable leaders, who were not only corrupt but who also systematically abused human rights with impunity. Those who did not blatantly abuse human rights became sit-in or life presidents. These leaders flourished under the glaring eyes of the OAU. Many of these leaders fell from power either through popular revolts as was the case of Mengistu Harmiriam (Ehiopia) and Siad Bare (Somalia); military coup in the case of Kwame Nkrumah (Ghana); armed rebellion as in the cases of Mobutu Sese Seko in Zaire (now Democratic Republic of Congo-DRC) and Samuel Doe (Liberia); democratic elections as in the case of Kenneth Kauda (Zambia); or through natural death while in power such as were the cases of Gnassengbe Eyadema (Togo) and Sani Abacha (Nigeria). Typically, these leaders received no condemnation from the OAU. To be sure, the logic of the cold war was largely responsible for the persistence, even survival, of many of these leaders. As strategic allies of the chief cold war protagonists, these leaders were protected against popular revolts. For example, when in I978 Mobutu's regime was threatened by rebellion in the Katanga province, French and Belgium troops, supported by US, expeditiously came to his aid (Schatzberg I997, 80). Largely as a result of this strategic importance, the west turned a blind eye to corruption and human right atrocities committed by these leaders against their citizens. The abatement of the Cold war, however, attenuated the strategic salience of African regimes and some like Samuel Doe and Mobutu readily fell to rebels in I99I and I997 respectively. Not only did the OAU remain silent on governance issues, but it was also constrained by the old and discredited principle of "non-interference" in the OAU charter from intervening in conflicts. This posture was, however, to change under 
the AU's Peace and Security Architecture (PSA).

\section{The AU Peace and Security architecture}

Recognising the central responsibility of conflicts and poor governance in the threat to peace and security, the Constitutive Act of the AU laid the foundations for a new security architecture on the continent. Article $3(\mathrm{f})$ of the Constitutive Act lists the promotion of "peace, security, and stability on the continent" as one of the key objectives of the AU, while Articles $3(\mathrm{~g})$ and $3(\mathrm{~h})$ seek to promote democratic governance and human rights respectively. Thus, the Constitutive Act set the AU apart from its predecessor. Two provisions of the Constitutive Act particularly relevant to the PSA are Article 4(h) which, consistent with the UN's doctrine of the Responsibility to Protect (R2P), authorises the intervention of the Union in member states "pursuant to a decision of the Assembly in respect of grave circumstances, namely war crimes, genocide and crimes against humanity"; and Art 4(j) which grants "the right of Member States to request intervention from the Union in order to restore peace and security." These provisions, in contrast to the posture of the OAU, marked a fundamental positional shift of the AU from "non-interference to non-indifference" (Mwanasali 2008). Moreover, the provisions underscored the AU's determination to directly confront acts of impunity and incidences where the state becomes a source of threat to the security of its citizens (Akokpari 20II). Importantly, the interference clauses redefined sovereignty, stripping it of its previously absolute status and prioritising the security and safety of people over the territorial integrity of states. It was under the powers of Art $4(\mathrm{~h})$ that the AU intervened in the conflicts in Somalia (2007), Darfur (2007) and Ivory Coast (2OII), among other countries.

A notable institution of the PSA is the Peace and Security Council (PSC), which was officially launched in May 2004. A key organ of the AU, membership in the PSC was a form of reward to countries which have been active in previous peace and security systems of the OAU. At the same time, membership also served as an incentive for countries to become more involved in the peace and security operations on the continent. Thus, as Adebajo Adekeye notes, membership is "based on four basic criteria: peacekeeping experience; capacity to pay; financial contribution to the AU's Peace Fund; and constitutional governance commitment" (Adekeye 2008, I33). The I5 members of the PSC were drawn from countries in each of the five sub-regions of the continent - North, South, East, West and Central Africa -pursuant to equitable regional representation. Ten of the I5 members are elected for a two-year term, while the remaining 5 serve a term 
of three years. While this arrangement ensured continuity, it was also a compromise between dominant states like South Africa and Nigeria, which wanted veto powers on account of their disproportionately bigger financial and material contribution to the AU on the one hand, and the broad range of countries who were opposed to the idea of veto. Thus, unlike the UN Security Council, no members of the AU PSC wield veto powers. Decisions on substantive issues are carried by a two-thirds majority vote. Generally, the PSC is to function like the UN Security Council in matters relating to peace and security. Article 7 of the Protocol on PSC mandates it to assume full responsibilities over issues relating to peace and security. This includes the prevention, resolution and management of conflicts and attendance to any issues that threaten regional peace and security (AU Protocol Establishing the Peace and Security Council, Art 2).

The Protocol establishing the PSC provided for an African Standby force (ASF) to be composed of the Standby Brigades of the five sub-regional blocks. Each sub-regional brigade was envisioned to number between 3,5005,000 troops (Kent and Malan 2003: 76). In addition to military personnel, the ASF was also to have police and civilian segments and together number 40,000 (Dersso 2009; Potgieter 2009). The PSC originally envisioned the ASF to be ready for rapid deployment to conflict spots by 2010 . However, the ASF is yet to be assembled and the AU, meantime, has to call on states to contribute troops when needed. The deployment of the ASF is to be the responsibility of the PSC (Sarkin 2008, 59). In the exercise of its functions, the PSC is advised by the Council of the Wise, a five-member panel of eminent persons, who serve for a three year-term and are eligible for reappointment for a second term. Article 20 of the PSC protocol mandates it to involve civil society "actively in the efforts aimed at promoting peace, security and stability in Africa." Other key institutions of the PSA include a Continental Early Warning System (CEWS) under the PSC. The CEWS office is to use appropriate "early warning indicators" such as economic, political, humanitarian and military from countries, analyse these and carefully track situations and take appropriate measures to forestall the outbreak of conflicts (Cilliers and Sturman 2004). A Military Staff Committee (MSC) composed of the representatives of military top brass of countries constituting the PSC is established under the PSC. The key function of the MSC is to advise the PSC on issues of peace and security. A final institution under the PSA is the Special Fund to which member countries make mandatory and voluntary financial contributions. In 20II, the AU increased the mandatory contribution of member states to the fund from six to seven percent (Report of the Executive Council 20II).

Equally worthy of note is the greater responsibility devolved to sub- 
regional organisations as part of the AU's PSA. In retrospect, the idea of formalising the role of regional organisations in conflict resolution and peace building developed from former UN Secretary General Boutros Boutros-Ghali's I992 Agenda for Peace. The Agenda called for burden sharing between the UN and regional organisations, especially in areas where the former was limited in its ability to maintain peace and security (United Nations I992). In the Agenda, Boutros-Ghali underscored the importance of regional organisations as first responders to conflict as a way of reducing the peacekeeping burden of the UN. A subsequent UN Report expanded on the merits of using regional organisations in peacekeeping noting their "comparative advantage in taking the lead role in the prevention and settlement of conflicts and [in assisting] the UN in containing them" (United Nations I995, 4). Boutros-Ghali's proposal was bolstered by the Economic Community of West African States' (ECOWAS) successful intervention in the conflicts in Liberia in I990 and Sierra Leone in 1997 (Levitt I998). The abatement of the cold war and Africa's loss of strategic importance to the west was attended by a corresponding decline in the willingness of western governments to either lead or be involved in peacekeeping operations (PKOs) in Africa (Adekeye and Landsberg 2000). Thus, a new urgency was created for the AU to assume greater, if not full, conflict management responsibilities on the continent. Western governments are, however, willing as the cases of Ivory Coast and Libya showed, to instigate "regime change" in countries where incumbent leaders are perceived as acting contrary to international norms or as a hindrance to the foreign policy agenda of the west. In such situations, western governments are prepared to side-line the AU.

Ideally, while the use of regional organisations in peace keeping carry the danger of promoting the parochial interest of intervening countries, it is nonetheless seen as more advantageous than the use of an international force. Among other things, regional peacekeepers have better familiarity with the region, including its cultural, social and historical terrain, which make them more effective on the ground. This factor partly explains why, with its superior weaponry and military technology, the US failed to outgun Somali militias during the former's intervention in I993-4. Further, geographical proximity lessens the financial cost of intervention and peacekeeping by regional actors. Moreover, regional forces can be assembled much faster than a multinational force. Above all, the sheer desire to mitigate the associated effects of conflicts on the region in the form of refugee flows, gunrunning and weapon proliferation, as well as general insecurity make regional actors more committed to peacekeeping than extra-regional actors (Adekeye 2002, I6). While the advantages of 
regional peacekeepers over extra-regional multinational forces is yet to be empirically demonstrated, it is fair to argue that ECOWAS' successes in the interventions in the Liberian and Sierra Leonean conflicts were largely due to the unique advantage enjoyed by the ECOWAS Monitoring Group (ECOMOG) as a regional peacekeeping force. Yet, while the AU and its subregional organisations have shown a strong inclination towards regional peacekeeping, they face numerous challenges, which undermine the longterm effectiveness of the AU's peace and security initiative.

\section{Challenges facing the Peace and Security Architecture of the $\mathrm{AU}$}

The old and perennial problem of inadequate finance and logistics, which afflicted the OAU, continues to undermine the AU and its PSA. In 20II, the AUs budget stood at \$260 million, which was grossly inadequate to cover its administrative costs, peacekeeping operations and the salaries of its 400-member staff. The entire AU budget of 20II was smaller than the $\$ 645$ million and $\$$ I.8 billion which the UN spent on UNOCI and UNAMID respectively between July 20II and June 2012 (United Nations 20I2). Even so, AU members contributed only 40 percent of the budget, the larger percentage coming from the EU, the US and China (The Economist 27 January 20II). The biggest source of the financial challenge is the inability of member states to pay up their yearly contributions. Five members Algeria, Egypt, Libya, Nigeria and South Africa - make the largest financial contributions. In 20II, these countries each contributed \$I million while the majority of member states paid much lesser amounts ranging from $\$ 160,000$ to as little as $\$ 20,000$ by Malawi (The Economist 27 January 20II). This truncated ability of the majority of member to make significant contributions has been coupled with the increasing demand of the AU to assume greater peacekeeping duties on the continent.

Related to financial constraints is the inadequate logistics at the AU's disposal. AU peacekeepers are often poorly equipped and overstretched. Largely as a result of these constraints the AU has had to rely on external partners for finance and logistical support in its PKOs (Saxena 2004, I86). The US and the European Union (EU) have been regular financial and logistical contributors to AU's PKOs. The AU Mission in Burundi (AMIB) was financed almost entirely by South Africa in 2003 until financial contributions from the EU and the US came in 2004. For that operation, the EU contributed about $€ 25$ million while contributions from individual 
EU countries brought in an additional $€_{30} 0$ million towards AMIB. In addition to logistical support, the US and EU have contributed $\$ 220$ million and $€_{\mathrm{I}} 6_{2}$ million respectively towards AMIS since the mission's inception (African Union 2006, Frazer 2006). China has since 2000 been making contributions towards the AU's conflict management efforts. In 2008, it donated \$II million and \$I.8 million towards humanitarian assistance and peacekeeping efforts respectively in Darfur (World Savvy Monitor 2008). By the close of 20II, Beijing became the largest contributor to AU's PKOs among the five permanent members of the UN Security Council, although its personnel are principally deployed in non-combat roles, mostly as engineers and transport experts (Ayenagbo et al 20I2). While helpful, regular reliance on extra-African financiers delays intervention and undermines the AU's ability to resolve conflicts on its own terms (Akokpari 20II: I6I). A further challenge is the hesitance, sometimes failure, of member states to pledge troops and where pledges have been made, fulfilment has been appalling. The AU has traditionally struggled to assemble peacekeepers for quick deployment to conflict zones.

\section{South Africa's controversial stances: a new challenge to the AU's PSA?}

A new and creeping challenge to Africa's PSA is the contradictory position of South Africa, a leading member of the AU, on crucial peace and security issues. In perspective, the crucial role of South Africa in Africa's peace and security initiatives cannot be overemphasised. As noted already AMIB was initially funded mainly by South Africa. Although Ethiopia and Mozambique provided troops, the bulk of the AMIB forces were drawn from South Africa. Along with ECOWAS, South Africa also played a central role in the attempts to resolve the previous conflicts in the Ivory Coast. It hosted peace talks between the warring factions in both the Ivorian and DRC conflicts between 2003 and 2005 and helped broker ceasefire agreements. South Africa's most recent conflict resolution/mediation efforts under the PSA of the AU were in Zimbabwe, Mauritania and Madagascar. In these countries the conflicts were successfully resolved although the peace remained tenuous. Pretoria's contribution to the PSA of the AU is cannot be underestimated.

Many of South Africa's recent peace efforts were initiated by Thabo Mbeki, whose involvement in continental peace negotiations cannot be seriously disputed. Mbeki has been key in the conflict resolution initiatives in the Ivory Coast conflict between 2003 and 2005, the DRC, Zimbabwe and has served as the chief negotiator in the Darfur and in the Sudan-South Sudan conflicts although as an envoy of the AU. As well, Mbeki has been 
pivotal in repositioning Africa in the new global political and economic order under the auspices of the AU. Moreover, Mbeki was part of the brains that restructured the OAU into the AU (Tieku 2004), while his role in reordering governance on the continent has equally been remarkable. He was influential in the promotion of the New Partnership for African Development (NEPAD), which among other things, is helping to improve upon human rights protection and good governance in Africa in return for western aid and investments; and the African Peer Review mechanism (APRM), which assesses a country's progress towards democracy, human rights and good governance (Hope 2005). Mbeki has used diplomacy and tact in dealing with the AU and individual states. He mastered the art of dealing with African leaders, including such errant presidents like Robert Mugabe (Zimbabwe) and Omar Al-Bashir (Sudan) to get them at least to the negotiating table with their opponents.

However, Mbeki's soft and overly diplomatic approach has been criticised for failing to resolve conflicts. His quiet diplomacy approach in the Zimbabwean conflict failed to yield dividends (Akokpari and Nyoni 2009). In spite of successfully brokering a peace deal between ZANU$\mathrm{PF}$ and the opposition Movement for Democratic Change (MDC) in the form of the Global Political Agreement (GPA) in 2008, the resultant unity government between the two contending political parties remained fragile, and characterised by mutual suspicion. Moreover, human right abuses and unilateral appointments to key positions were made by ZANU-PF without consultation with the MDC as stipulated in the GPA. To add, Mbeki controversially tried to get the International Criminal Court (ICC) to revoke the indictment of Al-Bashir on war crime and crime against humanity charges on grounds that the arrest and prosecution of the Sudanese leader would complicate the resolution of the Darfur and the KhartoumJuba conflicts (Akokpari 20II). Mbeki's soft and non-blame-apportioning posture was also evident in his failed mediation efforts in the Ivorian postelection conflict in 2010 as an AU envoy. Typical of his style, Mbeki wanted a compromise position, possibly the formation of a Zimbabwe-styled powersharing government to include Alassane Ouattara and incumbent Laurent Gbagbo. The formation of a unity government was, however, contrary to the position of ECOWAS and the AU, which both called on Gbagbo to cede power after losing the polls. In spite of this, Mbeki never really led South Africa to openly contradict the collective position of the AU on critical peace and security matters. This was, however, not to be the position under his successor, Jacob Zuma on the Zimbabwean, Ivory Coast, and Libyan conflicts. 


\section{South Africa- a torn in AU diplomacy?}

South Africa's position on the Zimbabwean, Ivory Coast and Libyan crises raised questions around Pretoria's neutrality as a mediator and about whether it truly represents Africa. It was widely thought that as a designated mediator by SADC in the Zimbabwean conflict, South Africa under Jacob Zuma would adopt a tougher and an uncompromising stance on Zimbabwe, in contrast to Mbeki's largely ineffective quiet diplomacy. During his campaign for the presidency, Zuma became openly critical of Robert Mugabe, demanding that the people of Zimbabwe be allowed to freely elect their leader. However, on assuming office, the South African leader surprisingly retracted from his tough posture. Like his predecessor, Mr Zuma rather "broke bread" with Mr Mugabe much to the chagrin of the opposition MDC. In 20I0, the president of the ANC Youth League (ANCYL), Julius Malema, then a close ally of Zuma, paid an official visit to Zimbabwe during which the ANCYL leader openly endorsed Mugabe as a legitimate leader while denouncing the MDC as a puppet of the West. Although the ANC eventually chastised Malema for his utterances, this did not convince the MDC that South Africa was an impartial mediator in the conflict. Meantime, the situation in Zimbabwe hardly improved as human rights violations were perpetrated by ZANU-PF against supporters of MDC, even with the establishment of the unity government in 2008 (Shaw 20II). Frustration with progress in Zimbabwe led MDC supporters and South Africans, who had hoped for the application of intense pressure on Mugabe, to question South Africa under Zuma as a neutral mediator.

Although not directly involved as a mediator, South Africa's position in the Ivorian conflict was equally controversial, if not oppositional to the stance of ECOWAS and the AU. The Ivory Coast conflict erupted when President Laurent Gbagbo who was widely believed to have lost the 28 November 20 Io presidential polls, refused to cede power to his rival Alassane Ouattara. While both ECOWAS and the AU were unanimous that Laurent Gbagbo had lost the election and were contemplating the use of force to enforce the will of Ivorians if he continued to cling on to power, South Africa's Minister of International Relations and Cooperation, Maite Nkoana-Mashabane, maintained that the outcome of the election was inconclusive (DIRCO 20II). This position emboldened the beleaguered Ivorian president to ignore calls to step down. ECOWAS and AU suspicion of South Africa's support for Gbagbo was heightened when in January 20II, a South African naval frigate, the SAS Drakensberg, docked off the Coast of Ivory Coast. The position of South Africa and the presence of its war ship off the Ivorian coast were seen by ECOWAS as not only undermining 
its authority but also countering the efforts of the AU at getting Gbagbo to cede power (Lynch 20II). Amidst mounting regional and international calls for him to quit, Laurent Gbagbo was emboldened to claim that he could still rely on seven of the 53 members of the AU including Angola, Uganda, South Africa, Democratic Republic of Congo, Gambia, Equatorial Guinea, and Ghana (ISS 20II). It was widely suspected that South Africa's position was partly responsible for the refusal of Gbagbo to cede power, hoping that divisions within the ranks of the AU members would weaken its resolve. The resulting impasse prolonged the violence in the country, which claimed over 3,000 lives and spawned thousands of refugees and internally displaced persons (Mail and Guardian I5 March 2012). The post-election conflicts was, moreover, characterised by massive human rights abuses believed to be perpetuated by forces loyal to both Gbagbo and Ouattara (Human Rights Watch 20II). Laurent Gbagbo was eventually arrested on II April 20II by a combined force of opposition and French forces.

If South Africa undermined regional efforts in the resolution of the Ivory Coast post-election conflict, it betrayed the AU on the Libyan crisis. As rebellion against Muammar Qaddafi gathered momentum in late 20II, the AU proposed a roadmap to resolve the conflict. At the core of the roadmap were proposed talks between the beleaguered Libyan leader and rebels that would lead to democratic reforms. The roadmap was, however, rejected by rebels who maintained that Qaddafi should play no role in the future of the country. Meantime, civilian casualties were mounting while refugee flows from Libya were escalating. Led by France and Britain, Western governments proposed a no-fly zone to protect civilians in an apparent attempt to weaken Qaddafi's ability to quell the rebellion. In the light of possible marginalisation in the resolution of the conflict, the AU resolved not to support any UN Security Council resolution that sought to use force or external military intervention of any sort in Libya. However, less than a week after the passing of the AU resolution, on I7 March South Africa, one of the Io non-permanent members of the UN Security Council, surprisingly voted in favour of Resolution I973. The resolution established a no-fly zone over Libya and also authorised NATO to use "all necessary measures" to protect civilians. South Africa's support for the Resolution was disturbing for not only contradicting the collective position of the continent, but also seriously undermining the AU's peace proposals for Libya. South Africa justified its support for Resolution I973 on grounds of its concerns for protecting civilians (United Nations 20II). However, Pretoria ought to have foreseen that a resolution authorising the use of "all necessary means" was open to various interpretations and given the West's obsession with "regime changes" in the South in the post-Cold War era, Resolution I973 
would provide both the context and pretext for the overthrow of Muammar Qaddafi. South Africa made frantic efforts to stop the NATO bombing once it began, by declaring that NATO's bombing of Libya was an abuse of Resolution 1973 (Mail and Guardian I4 June 20II). However, it was too late - the irreparable damage had been done; the West had fully grabbed the opportunity it had been looking for to effect regime change in Libya.

\section{Implications of South Africa's controversial stance}

South Africa's action had critical implication for the unity of the AU, but also for the organisation's PSA. It might be plausibly argued that the inability of the AU to elect the Chair of its Commission - the topmost job in the continental body - on $30^{\text {th }}$ January 2012 during its eighteenth Summit in Addis Ababa, might be linked to Pretoria's controversial stance on the AU's peace initiatives. The contest for the Chair of the AU Commission became a straight two-way race between Jean Ping, the Gabonese, who was elected in 2008 and who was seeking a second term and Nkosazana Dlamini Zuma, the South African Home Affairs Minister, who was challenging for the job. After three rounds of voting none of the candidates secured a twothirds majority vote needed for election. During the fourth round of voting Jean Ping still failed to secure two-thirds of the total votes after DlaminiZuma withdrew. The impasse was unprecedented; the election of previous Chairpersons of the Commission - Amary Essy (Ivory Coast) 2002-2003; Alpha Oumar Konare (Mali) 2003-2008; and Jean Ping 2008-2012 - had never required second rounds of voting. In fact, there has never been two candidates contesting at a time. Consensus was always the norm with official voting legitimising the choice. Following the failure to obtain a winner, a new round of voting was scheduled for the next AU summit in mid-July 20I2. The weeks preceding the July summit saw increased lobbying of African states by the contending candidates. When votes were eventually cast on $14^{\text {th }}$ July, Nkosazana Dlamini Zuma won, polling 60 percent of the 54 votes during the third round of voting (BBC 2012).

Some observers argued that the voting in January and July was done along linguistic lines with Anglophone Africa supporting Dlamini Zuma and Fracophone countries voting for Jean Ping (Cilliers and Okeke 20I2, I). It was also apparent that the linguistic divide was overlaid by regional divisions with SADC countries lining up behind Dlamini Zuma and ECOWAS members behind Jean Ping. Whatever the truth might be Jean Ping's challenger ought to have won the contest during the January vote since no former Chair of the Commission has ever contested for a second term. The failure of the South African candidate to beat Jean Ping perhaps 
highlighted Africa's suspicion of South Africa, a suspicion heightened by Pretoria's controversial stance on the crises in Ivory Coast and Libya. Without doubt Pretoria's contradictory position on the Ivory Coast and Libyan crises raised uncomfortable questions about the direction it was likely to lead the continent. Some countries might have calculated that it would be too dangerous to entrust the top-most job of the continent into the hands of a country which did not seem to speak the same language as the rest of the continent. The failure of Dlamini-Zuma to win the contest in January 2012 was therefore a rejection of South Africa's leadership in the Commission. Given its tendency to follow a unilateral foreign policy different from the collective position of the continent, along with its affability with the West, the inevitable question that beamed in the minds of African leaders was whether Pretoria could be a trusted spokesperson of Africa on critical regional and international issues.

The eventual election of Nkosazana Dlamini Zuma may have delivered the AU Commission chair, but may not have restored unity to the AU, nor could it be said to have forestalled potential problems for the organisation. On the contrary, the election of the South African candidate could be the beginning of more schisms and suspicions in the AU for a number of reasons. First, there is an unwritten agreement among AU members that the chairship of the AU Commission should not be contested by any of the leading member states - Algeria, Egypt, Libya, Nigeria and South Africa. This practice was similar to what obtained in the UN where the Secretary-General has never been elected from any of the five permanent members of the Security Council. The election of a candidate from South African thus breached this long-standing gentleman agreement. Trouble and dissension could emerge if Nigeria which, like South Africa, makes huge contributions to the AU budget decides to contest for the office next time around. Second, South Africa's cross-continent lobbying and the eventual election of Dlamini Zuma's may suggest that the chairship of the AU Commission is guaranteed only for those countries with bigger financial muscles. This could potentially create a "coalition of the weak" who will constantly oppose the economically powerful member states, thus creating a new and disconcerting fault line in the AU. Importantly, the longstanding election of AU Commission chair by consensus may have ended, paving the way for potentially divisive politics and damaging implications for AU's PSA. 


\section{Conclusion}

The African Union's PSA was an innovation aimed at proactively tackling Africa's seemingly intractable security challenges. The PSA was also to distinguish the AU from the OAU, which lacked any structured conflict management programme. In addition to the AU's recognition of subregional organisations as key partners in regional conflict management, the PSA was also characterised by such novel and security-enforcing institutions as the Peace and Security Council, the African Standby force, the Panel of the Wise, the CEWS, the Military Staff Committee and the Special Fund. In establishing the PSA, Africa showed a commitment and initiative, at least in theory, to confront the perennial conflicts on the continent. The PSA was thus ideally set to be an effective tool. However, it faced a number of challenges, not least of which included inadequate funding and logistics as well as the lack of sufficient troops for expeditious deployment to securitythreatened spots. Recently, however, the contradictory position of South Africa on the AU's stance on the Ivory Coast and Libyan crises has added a new challenge to the list of the continent constraints. Not only did South Africa's action deprive the AU of a united voice on serious security issues, but it also divided the organisation. This was partly seen in the widely publicised AU's failure to elect the Commission's chair in January 2012. Although the chair was eventually elected in July 20I2, the combined effect of these challenges may vitiate the already tenuous position of the AU in conflict management.

\section{REFERENCES}

Adam, Hussein. I995. "Somalia: a terrible beauty being born”, in William Zartman (ed.) Collapsed States: The Disintegration and Restoration of Legitimate Authority (Boulder: Lynne Rienner): 69-89.

Adedeji, Adebayo. I999. "Comprehending Africa's Conflicts", in Adebayo Adedeji (ed.) Comprehending and Mastering African Conflicts: the Search for Sustainable Peace and Good Governance (London: Zed Books)

Adejumobi, Said. 200I. "Citizenship, Rights and the Problem of Conflicts and Civil Wars in Africa." Human Rights Quarterly 23(I): I48-I70.

Adekanye, Bayo. I995. "Structural Adjustment, Democratisation and Rising Ethnic Tensions in Africa', Development and Change, 26(2):335374 . 
2002. Building Peace in West Africa: Liberia, Sierra Leone and Guinea Bissau, (Boulder, Co: Lynne Rienner).

. 2008. "The Peacekeeping Travails of the AU' in John Akokpari, Tim Murithi and Angela Ndinga-Mvumba (eds.) The African Union and its Institutions, (Johannesburg: Jacana Press): I3I-I62.

Adekeye, Adebajo, e Landsberg, Chris. 2000. "Back to the Future: UN Peacekeeping in Africa" International Peacekeeping 7(4): I6I-I88.

African Union. 2006. "Report of the Chairperson, (PSC/PR/2 (XLV)" I2 Janeiro.

African Union Protocol Establishing the Peace and Security Council. 2002. Article 2.

Akokpari, John. 2008. "You don't belong here: citizenship and Africa's conflicts - reflections on Ivory Coast" in Alfred Nhema and Paul Zeleza (eds.) Roots of African Conflicts: The Causes and Costs, (Oxford: James Currey): 193-228.

. 20II. "Limited Capabilities, Great expectations: the African Union and Regional Conflict Management" in Stefan Wolff and Christalla Yakinthou (eds.) Conflict Management in Divided Societies: Theory and Practice (New York: Routledge):I5I-I66.

Akokpari, John, e Nyoni, Tavaka. 2009. "Reassessing the Politics of Neo-colonialism and African Solidarity: Contextualizing Thabo Mbeki's Quiet Diplomacy on Zimbabwe” Affrika: Journal of Politics, Economics Q Society, I(I): II7-I33.

Ayenagbo, Kossi; Njobvu, Tommie; Sossou, James, e Tozoun, Biossey. 2012. "China's peacekeeping operations in Africa: From unwilling participation to responsible contribution" African Journal of Political Science and International Relations, I6(2): 22-32.

BBC. 20I2. "AU chooses Nkosazana Dlamini-Zuma as leader" I5 July. Acesso em 20 outubro, 20I5. http://www.bbc.co.uk/news/world-africa-I8846210

Brown, Michael. I995. Africa's Choices: After Thirty Years of the World Bank (Harmondsworth: Penguin Books).

Cilliers, Jackie, e Sturman, Kathrine. 2004. "Challenges facing the AU's Peace and Security Council" African Security Review I3(I): 97-I04.

Cilliers, Jakkie, e Okeke, Jide. 20I2. "The Election of Dr Dlamini-Zuma As AU Commission Chairperson: Towards Pan-Africanism and African Renaissance?” ISS Policy Brief. No 33, July.

Copson, Raymond. I994. Africa's Wars and Prospects for Peace (New York: M.E. Sharp) 
Department of International Relations and Cooperation (DIRCO). 20II. "South African Government status on the Results of the Presidential Elections in Cote d'Ivoire' 24 March. Acesso em I2 de outubro, 2015. http://www.dfa.gov.za/docs/20IIpq/pqI3.html

Dersso, Solomon. 2009. "The Role and Place of the African Standby Force within the African Peace and Security Architecture" Institute For Security Studies, ISS Paper.

Frazer, Jendayi. 2006. "Briefing of the Assistant Secretary of State for African Affairs, 28 April. Acesso em Io setembro, 2015. https:// georgewbush-whitehouse.archives.gov/ask/text/20060428.html

Goodhand, Jonathan. 2006. Aiding Peace? The Role of NGOs in Armed Conflict, (Boulder: Lynne Rienner).

Guest, Robert. 2004. The Shackled Continent: Africa's past, present and the future, (London: Macmillan).

Human Rights Watch (HRW). 20II. "Ivory Coast inquiry into post-election violence lacks credibility" Washington Post, 23 fevereiro.

Hyden, Goran. I992. "Governance and the Study of Politics" in Goran Hyden and Michael Bratton (eds.) Governance and Politics in Africa, (Boulder: Lynne Rienner).

Institute For Security Studies (ISS). 20II. "Cote d'Ivoire: Will AU Meeting Finally Resolve Political Standoff?”. Acesso em I5 outubro, 2015. http://allafrica.com/stories/20II03IIo9i6.html

Kampe Hope. 2005. "Toward Good Governance and Sustainable Development: The African Peer Review Mechanism" Governance I8(2), April: 283-3II.

Kent, Vanessa, e Malan, Mark. 2003. “The African Standby Force: Progress and prospects" Africa Security Review I2(3).

Lake, David, e Rothchild, Donald. I996. "Containing Fear: the origin and management of ethnic conflicts" International security, 2I(2): 4I-75.

Laremont, Ricardo. 2002. "The Causes of Warfare and the Implications of Peacekeeping in Africa”, in Ricardo Rene Laremont (ed.) The causes of Warfare and the Implications of Peacekeeping in Africa, (Portsmouth: Heinemann)

Levitt, Jeremy. 1998. "Humanitarian Intervention by Regional Actors in Internal Conflicts: The Cases of ECOWAS in Liberia and Sierra Leone", Temple International and Contemporary Law Journal, I2(2): 333-375.

Lynch, Colum. 20II. "On Ivory Coast diplomacy, South Africa goes its own way”. Acesso em Io outubro, 20I5. http://turtlebay.foreignpolicy. 
com/posts/20II/02/23/on_ivory_coast_diplomacy_south_africa_ goes_its_own_way

MacMullin, Colin, e Loughry, Maryanne. 2004. "Investigating Psychosocial Adjustment of Former Child Soldiers in Sierra Leone and Uganda" Journal of Refugee Studies, I7(4): $460-472$.

Mail and Guardian. 20II. "Zuma lashes Nato for 'abusing' UN resolutions on Libya" I4 June 20II. Acesso em II outubro, 20I5. http://mg. co.za/article/20II-o6-I4-zuma-lashes-nato-for-abusing-un-resolutions-on-libya

Mail and Guardian. 20I2 "ICC finds mass graves in Côte d'Ivoire" I5 March 2012. Acesso em Io outubro, 20I5. http://mg.co.za/article/20I203-I5-icc-finds-mass-graves-in-cte-divoire.

Mwanasali, Musifiky. 2008. "From Non-Interference to Non-Indifference: The Emerging Doctrine of Conflict Prevention in Africa" in John Akokpari, Tim Murithi and Angela. Ndinga-Mvumba (eds.) The African Union and its Institutions (Johannesburg: Jacana Press): 4I-62.

Ndinga-Muvumba, Angela. 2008. "Accelerating the Response: An Evolving African HIV/AIDS Policy?” in John Akokpari, Tim Murithi and Angela Ndinga-Muvumba (eds.) The African Union and its Institutions, (Johannesburg: Jacana Press): I63-I82.

Obi, Cyril. I997. "Economic Adjustment and the deepening of environmental conflict in Africa" Lesotho Social Science Review, 3(I):I3-29.

Packer, Corinne, e Rukare, Donald. 2002. "The New African Union and Its Constitutive Act" The American Journal of International Law, 96(2).

Potgieter, J. 2009. "Peacekeeping Forces for Peace Support Operations in Africa". Acesso em 20 abril, 20I5. http://www.apsta-africa.org/ news/articleo40809.php.

Report of the Executive Council, Eighteenth Ordinary Session, $24-28$ January 20II, Addis Ababa, Ethiopia, p. 7. Acesso em I2 outubro, 20I5. http://www.peaceau.org/en/article/executive-council-eighteenth-ordinary-session-24-28-january-20II-addis-ababa-ethiopia

Sarkin, Jeremy. 2008. "Humanitarian intervention and the Responsibility to Protect in Africa", in John Akokpari and Daniel Zimbler (eds.) Africa's Evolving Human Rights Architecture (Johannesburg: Jacana Press): 24-44.

Saxena, Suresh. 2004. "The African Union: African Giant Step Towards Continental Unity" in J. M. Mbaku (ed.) Africa at the Cross Roads: Between Regionalism and Globalisation, (Wesport, CT: Praeger): I63I90. 
Schatzberg, Michael. I997. "Beyond Mobutu: Kabila and the Congo" Journal of Democracy, 8(4): 70-84.

Shaw, Angus. 20II. "Zimbabwe coalition failing to end violence' Mail and Guardian [Johannesburg] II February. Acesso em I3 outubro, 20I5. http://mg.co.za/article/I970-oI-oI-zimbabwe-coalition-failing-to-end-violence

Skinner, Elliott. I999. "Child Soldiers In Africa: A Disaster for Future Families" International Journal on World Peace, I6(2): 7-22.

Suliman, Mohamed, e Omer, Ahmed. I994. "The Environment: a new dimension in Sudan's political and social landscape" Africa World Review, November-April: 23-25.

The Economist. 20II "The African Union short of cash and teeth" 27 January 20II. Acesso II novembro, 20I5. http://www.economist.com/ node/18014076

Tieku, Thomas. 2004. "Explaining the Class and Accommodation of interests of major actors in the creation of the African Union" African Affairs, I03(4II): 249-267

United Nations. I992. An Agenda for Peace: Preventive Diplomacy, Peacemaking and Peacekeeping (New York: United Nations).

. I995. Improving preparedness for conflict prevention and peacekeeping in Africa: Report of the Secretary-General, UN doc. A/50/7II and S/I995/9II, I November.

. 20II. UNSC Resolution I973 - "Security Council Approves "No-Fly Zone" Over Libya, authorizing "All Necessary Measures" to protect civilians, by vote of Io in Favour with 5 abstentions'. Acesso em I5 outubro, 20II._http://www.un.org/News/Press/docs/20II/ scio200.doc.htm

2012. "Peacekeeping Fact Sheet". Acesso em 2 junho, 2016. http://www.un.org/en/peacekeeping/resources/statistics/factsheet.shtml/

. 20I6. "Peacekeeping Fact Sheet". Acesso em 2 junho, 2016. http://www.un.org/en/peacekeeping/resources/statistics/factsheet.shtml

World Savvy Monitor. 2008. 'The Situation in Sudan and Conflict in Darfur', Issue I, 26 May 2008. Acesso em 20 novembro, 20I5. http:// worldsavvy.org/monitor/index.php?option=com_content\&view=article\&id $=75 \&$ Itemid $=95$. 


\section{ABSTRACT}

The African Union established a Peace and Security architecture to prevent and resolve conflicts, which have remained endemic on the continent. The initiative was also to distinguish the AU from its predecessor, the Organisation of African Unity, which had an appalling record in conflict resolution. However, in addition to the familiar challenges of financial constraints and perennial conflicts, the PSA faces a new challenge in the form of contradictory postures by South Africa on critical security issues. Together, these challenges vitiate the ability of the AU to swiftly end conflicts. As well, South Africa's contradictory positions on certain security issues undermined unity mong AU members. The latter was demonstrated in the initial lack of consensus in the election of the Chairperson of the AU Commission.

\section{KEYWORDS}

OAU; AU; Peace and security; conflicts; governance; South Africa.

Received on June 6, 2016. Approved on August 4, 2016. 